\title{
Risk Management Design on Village's Financial Activities: A Case Study of Barabali Village, Central Lombok
}

\author{
Omar Shazaki Dilaga \\ Department of Economic \\ Faculty Economic and Busines Universitas Indonesia \\ Depok, Indonesia \\ sha_zaki@yahoo.co.id
}

\author{
Muhammad Ichsan \\ Department of Economic \\ Faculty Economic and Busines Universitas Indonesia \\ Depok, Indonesia \\ muhammadichsan@yahoo.com
}

\begin{abstract}
This study aims to develop risk management in a village's financial activities. Such management is aimed at assisting villages, local governments and even the central government in looking at the village's financial condition and providing solutions to control problems found in its financial activities. This research uses a qualitative method. The data used in this study are primary and secondary data. The primary data was collected through interviews and observation. The secondary data was obtained through documentation and a literature study. The risk management concept from the Project Management Institute is used in this paper. The impact and possibilities' scale are adopted from the Ministry of Finance's risk guidelines, as are the level and risk appetite. Two theoretical parameters are adopted in the research by considering the conformity of a village in using them. The second one, agency theory, is used to see the role of principal and agent in village's financial activities. This research shows how risk management may help villagers manage their financial activities. This instrument can be used by the relevant regional work unit (OPD) in evaluating villages. Additionally, the result of the study can be used as a groundwork plan in conducting an audit by government internal supervisory apparatus (APIP).
\end{abstract}

\section{Keywords—Risk management, risk, control, village}

\section{INTRODUCTION}

Law number 6 (year 2014) pertaining to villages, where they are granted the authority to manage funds independently, can be seen as a new challenge for each region in guarding the use of funds sourced from both the central (APBN) and the regional (APBD) governments. According to the Ministry of Finance [1], the total funds disbursed in 2015 to 74,093 villages were $\mathrm{Rp} 20.7$ trillion so that, on average, each village received Rp772,697,000. Although the distribution of funds differs from one village to another due to the proportional allocation of village funds, based on population, the poverty line, the area of the village, and the geographical difficulty index, the funds provided for any one village are considerable. In 2016 , this funding increased by about $49 \%$ with 74,754 villages receiving an average allocation of $\mathrm{Rp} 1,151,747,000$ (USD 81,131) per village.

A large amount of funds allocated by the state, wherein the amount is much greater than the amount that has been managed by the villages before, has entailed great consequences in the management process. [2] says from 2012 to 2017, the Indonesian National Police discovered 214 cases of mismanagement of village finances involving a budget of Rp46 billion. The management problems that occurred in villages along with the large amount of money that villages carried can be seen as governance problems. [3] conveys that public accountability is an important point in organizing good governance of public organizations comprised of institution serving the public interest, managing public funds, free from corruption, and obedient to the law. Consequently, some tools are needed to overcome the problems of village financial management. One way to resolve problems in the public sector is to improve accountability in governance in which there is a system of integrity, internal control systems, and leadership quality [3]. In the context of village financial management, the problems can be translated into the human resources of the village apparatus, the performance of village counseling, the supervision by the villagers themselves, and the supervision by the local government. To support accountability and transparency, public sector organizations should pay attention to risk management and technology [4]. Doing so means that one of the tools or ways that can be used to overcome the problem of governance is the implementation of risk management. Furthermore, in the management of village finances, implementation of risk management can help prevent early abuses of existing funds in the village and provide appropriate control over the risks. With the existence of risk management, according to [5], management can effectively face the uncertainty of an event in the future and respond to things that have a negative impact by reducing the likelihood of the occurrence of an event.

This research has the same frame of mind as [6] —research whose result is seen in compiling a risk management design. The difference between this research and [6] lies in themes, objects, and data. The theme of this object is the management of village finances, while in [6] lies the implementation of information system outsourcing projects. The object used is also different, since in this study the object is the village government of Barabali (1,320 kilometers east of Jakarta), while in [6] is the audit board of the Republic of Indonesia (BPK RI). Many kinds of risk management research have been completed. However, this research is different from previous studies because using risk management in village's financial activities brings its own level of uniqueness.

By considering the facts mentioned above, this study aims at designing risk management on village's financial activities as the implication of managing fund. This research is important to conduct because the villages need some kind of tools that can help them overcome governance problems. Besides, risk management in a village's financial activities can also help all the stakeholders involved (central and regional 
governments) to monitor and evaluate the village's financial activities. We chose Barabali village as the locus of the study based on some considerations that will be explained further in the analysis. Some conditions found in the research object are:

- The Barabali village government has not identified their financial activities' risk yet.

- The absence of a risk map to see the risks that may arise and have an impact on the management Barabali village government.

- The absence of risk-related strategies that have a high impact on the village's financial activities of the Barabali village government.

- Based on these problems, the research questions are:

- What are the risks faced by the village in managing the finances of the Barabali village government?

- How should potential risks that have an impact on Barabali village government be mapped into a risk map?

- How are the risk control strategies that have had a high impact on the financial activities of the Barabali village government faring?

Risk management on the village's financial activities is aimed at assisting both the village governments, local governments and even the central government in looking at the financial management conditions of a village and providing solutions through control measures pertaining to problems found in village financial management.

\section{THEORETICAL REVIEW}

This research begins with the definition of the management of state [7], regional [8], and village [9] finances. It aims to use the same definition for a village's financial management and design the stages of its activities. After that, this research proceeds to the explanation of risk management, in which there are definitions of risks by [5] and [10], types of risks proposed by [11], [12], and [1], and risk management benefits explained by [5], stages of risk management explained by [13], [14], and [15], just what risk management in the public sector conveys [16], and risk management relationships with internal audit explained by [17] and [5].

Thus, these studies indicate what risks arise in the management of village finances, as well as the basis for formulating risk management and a measurement scale. Furthermore, the study also outlines the agency theory by Jansen (2000), Lambert (2001) in [18] to provide a comprehensive theoretical framework to understand the activities or processes within an organization from both principal and agent perspectives. It also explains three agency problems that usually occur in organizations (Copelan and Weston, 1998 in [19]). Besides, Adams (1994) in [19] describes the function of the internal auditor in the principalagent relationship.

Moreover, previous research about risk management that been used in this study are research conducted by [20], [21], [19], and [6] that discusses the design of risk management conducted both in private and public sectors, as well as risk management at the organizational and project level. The design of risk management in these studies appears as a consequence of problems that occur in the field. The results of these studies show that risk management has become an instrument proposed to overcome problems.

\section{RESEARCH METHODS}

This research was undertaken with a qualitative approach. In this study, we use a methodology [13] consisting of identification, analysis and risk response of an activity (project) as the concept to conduct risk management on villages' financial activities. Additionally, we use the reference from [14] in compiling the impact scale and feasibility of sufficient detail to explain the impact and possible risks on village's financial activities. The reference from [15] is also used to determine the appetite and acceptable level of risk. These guidelines are used with consideration of the convenience of the village to use them. The study is conducted in three stages: (1) identifying existing risks on village's financial activities, (2) developing risk maps, and (3) developing risk-related strategies that will likely have significant impacts on the village's financial management.

The first step in this research is to identify what risks exist in the village's financial activities. According to Cooper (2010) in [22] to be able to identify any risks in the financial management of the villages, the researchers do a literature review. It comes from the evaluation of results by [1] and [12] and the supporting documents like regulations of governing village's financial management processes (RPJMDesa, RKPDesa, Kepdes, and Perdes), other documents related to village's financial management. Moreover, the identification of risks to village financial activities is also obtained from interviews with parties involved in the financial management of Barabali village. These parties include Barabali village's government, which became the object of the research, DPMD of central Lombok as a supervisor of the village finances, and the inspectorate of central Lombok as an internal auditor of the government that has responsibilities to verify the use of the funds (APBD). Interviews were conducted with unstructured interview methods when exploring problems. According to [23], this method can help identify critical issues and resolve them.

The second phase of this research is to develop a risk map based on the results of risk identification and risk assessment. Risk assessment guidelines are the combination of BPKP and Ministry of Finance guidelines. The scale of impact and likelihood are adopted from [14] as it is considered sufficiently detailed to outline the impacts and possibilities regarding village financial activities, while the level and risk appetite adopted is from [15] as they are considered easy to understand for the villagers, DPMD, and inspectorate.

The final step in this research is to develop risk-related strategies that have a significant impact on village financial management. After mapping the risks, we consider the appetite for risk. Furthermore, the risks that have significant impact would be grouped and seen whether the village has a control strategy or not. We would set up the necessary control measures to the risks that do not have control issues. The compiled strategies are the result of structured interviews with resourceful persons, a literature review carried out against those risks, and observation from the study site. 


\section{A. Unit Analysis}

The object of this research is Barabali village government that is considered to be one of the villages performing financial management. This research also looks at the role of central Lombok Government (DPMD) and central Lombok inspectorate (local government's internal auditor) in village development that includes village financial management.

The existence of several problems and news about the poor management of village finances in central Lombok were the reasons why the central Lombok was chosen as the study region. Based on the Audit Result Report of [24], for fiscal year 2016, in central Lombok there are 27 villages that have yet to submit their reports on the realization of the use of village funds. Additionally, there are several cases of village financial management that appear on online news portals, such as:

- According to [25], delayed distribution of village funds in central Lombok due to poor village administration in preparing their report (LKPJ) regarding village funds.

- According to [26] many cases of fraud occur in villages. The head of the village from several places are now involved with the law in relation to the village's budget.

However, amidst the large number of bad financial management cases in central Lombok, there is one of the villages that performed good financial management: Barabali village - a fairly superior village in that area even on a national scale. The evidence shows [27] that Barabali village is the winner of the most accountable and transparent village (DPIB) in national level competition that was organized by the Central Information Commission of the Republic of Indonesia. Based on the interviews with the Regent of central Lombok and the head of community and village empowerment of central Lombok (DPMD), Barabali village recommended itself as the object of this study. Simply stated, it is considered to be capable of managing its finances well. Accordingly, [5] risk is inherent in the activities of each organization. Hence, as good as the financial management of a village may be, the risks will still appear in every activity. This study explored what risks were emerging and have had a major impact on the financial activity of the adept managers of the Barabali village government.

\section{FINDINGS}

\section{A. Risks Identified in Barabali Village's Financial Activities}

Some risks in village financial management that can be identified based on the foregoing stages are:

- Planning Stage. In the planning stage, there are four risks that have occurred. First, APBDesa is not prepared according to the village's needs. Second, the village's planning and accountability are not sufficiently transparent. Third, different understandings and capacities regarding the village apparatus in carrying out its governance exists (e.g., preparing RPJMDesa, RKPDesa, and APBDesa). Last, the village government has been late in writing up the APBDesa.
- Distribution Stage. In the second stage, there were also four risks found. First, there was the delay in the distribution of village funds from RKUN to RKUD. Second, there was a delay in the distribution of funds allocated to the Village from RKUD to RKD. Third, there was a delay and/or withholding of funds to the village. And the last is the establishment of new village (formation of new villages).

- Implementation and Administration Stage. Thirteen risks occurred at this stage. They were (a) local government was late in establishing a Perbup/Perwali on fund allocations to villages, Guidelines on Financial Management and Village Assets, and Procurement of Goods/Services in the Village; (b) duplication of financing for the same activities/projects from different financing sources; (c) use of funds in the village that are not in accordance with their intended use or instructions for use; (d) the realization of absorption or use of funds in villages is low (i.e., planned programs are not realized yet); (e) the process of procurement of goods and/or services and mechanism for disbursement of funds from the village's petty cash is not in accordance with the provisions or regulations; (f) tax liability has not been maximally implemented; (g) misappropriation of funds in the village (e.g., fraud, taking village funds for personal use); (h) loss or theft of money (from the village's fund); (i) accumulation of excess balances (SiLPA) in RKUD or RKD; (j) overpricing of the procurement of goods and/or services in the village; $(\mathrm{k})$ the output of funds managed by the village was not utilized; (1) information system was down or experiencing interruptions such as input errors in the use of Siskeudes; and (m) BUMDesa suffered losses that in turn burden village finances.

- Reporting and Accountability Stage. There are five risks founds at this stage. The first risk was Pemdes is late in submitting accountability reports on the use of funds (APBDesa and Dana Desa). The second risk is the local government was late in submitting a recapitulation of accountability reports on the use of funds from villages. The third risk was the obligation to compile an accountability report that ended up being not in accordance with the standard and did not flow from sufficient evidence. The fourth risk was that few villages use the village financial system (Siskeudes) as the basis for village financial reporting. And the last risk was the fear of village's apparatus being involved in legal cases due to administrative errors and/or nuisance.

- Supervision Stage. The last stage was the supervision stage. Four risks appeared at this stage. First, there was overlapping authority between the Ministry of Villages and the directorate general of village government of the Ministry of Home Affairs in terms of development and village development, monitoring, and evaluation. Second, there was supervision from the regional inspectorate of village's financial activities was ineffective. Third, there was ineffectiveness in the public complaints channel (i.e., the whistleblowing system) to report on or complain about the village 
government's performance. Last, there was an unclear scope of authority and supervision by the sub-district.

\section{B. Risk Map of Barabali Village's Financial Activities}

The criteria for assessing risk levels are using the fivescales of the likelihood and impact. Furthermore, the results of this assessment and analysis are used to determine the risk appetite, as well as the risk map. Based on the results of the assessment, the resulting risk map:

Three risks were categorized as very high risk, two risks were categorized as high risk, twelve risks were categorized as moderate, and thirteen risks were classified as low risk. Overall, the level for all the risks involved in village financial activities in Barabali village is at moderate level. The type of risk that Barabali village is willing to take is moderate, meaning that they will mitigate very high and high risks.

\section{Strategy against the high risks in Barabali village's financial} activities

1) Risks that fall into very high categories:

- The fear of village's apparatus in legal cases due to administrative error and/or nuisance. Controlling activities that can be done to mitigate the impact of this risk is DPMD and inspectorate of the region for socialization, workshop, and assistance to villages that find it difficult to organize their governments. Additionally, by appointing a competent village's assistant with a good recruitment mechanism process, they can mitigate this risk. In Barabali village, this risk is a mutual concern between the inspectorate of central Lombok, DPMD of central Lombok, and Barabali village government as it is deemed to occur at any time and has a significant impact on the village government. Control activities that have been implemented by the Barabali village government are enriching each village's apparatus by understanding the existing rules, strengthening the information system in the village, and carrying out activities according to the procedures and rules that applied.

- Overlapping authority between the Ministry of Villages and the directorate general of village government of the Ministry of Home Affairs in terms of development and village development, monitoring, and evaluation. Control activities that can be undertaken to mitigate these risks are coordination (i.e., collective agreement on monitoring, and evaluation of the use of funds for villages or APBDesa between Ministry of Villages and the directorate general of village government of the Ministry of Home Affairs), and the creation of assurance maps by the central government (i.e., Ministry of Finance, Ministry of Villages, and Ministry of Home Affairs). In Barabali village, these risks often occur as well as the clash of rules and authorities that are considered quite confusing for the village government in implementing financial management and governance. The usual action of Barabali village government related to this risk is the coordination with DPMD and inspectorate.

- Local government is late in establishing a Perbup/Perwali on funds allocation to villages, Guidelines on Financial Management and Village Assets, and Procurement of Goods/Services in Villages. Control activities to mitigate these risks are the commitments of the local government to provide a timeline for the completion of the Perbup by the local government itself. This risk is often perceived as disturbing the implementation of financial management and administration of village administration. The control activities that have been done by the village undertaking good planning based on prior years' experience and maximizing the role and function of the village's apparatus.

2) Risks that fall into the high category

- Tax liability has not been maximally implemented. To minimize this risk, the control activities that can be done are DPMD, inspectorate, and the directorate general of taxes for socialization and counseling about taxation, make a tax helpdesk in the village and do audits related to tax obligations. There is need of commitment from village government to pay more attention to its taxation function. In Barabali village, this risk is common and it becomes a concern for DPMD, inspectorate, and village government. The existing control activities for this risk are the DPMD conducting coaching and reminding the village apparatus to maximize its function in terms of taxation.

- The local government is late in submitting a recapitulation of accountability reports on the use of funds from villages. Control activities that can be done to minimize this risk is the local government conducts regular monitoring. Additionally, the Ministry of Village can provide a fair system about reward or punishment for motivating the village government to submit their accountability reports on time. In central Lombok, this risk is often encountered due to the existence of several villages that are often late in providing their reports. The usual controlling activities by DPMD are guiding and giving assistance to villages that are experiencing problems.

TABLE I. RISK MAP OF BARABALI VILLAGE’S FINANCIAL ACTIVITIES

\begin{tabular}{|c|c|c|c|c|c|}
\hline \multirow[b]{2}{*}{ Likelihood } & \multicolumn{5}{|c|}{ Impact } \\
\hline & $\begin{array}{l}\text { Negligible } \\
\text { (1) }\end{array}$ & Minor (2) & $\begin{array}{l}\text { Moderate } \\
\text { (3) }\end{array}$ & $\begin{array}{l}\text { Significant } \\
\text { (4) }\end{array}$ & Severe (5) \\
\hline Very Likely (5) & Moderate (2.d.) & High Risk (3.f.) & Very High Risk & Very High Risk & Very High Risk \\
\hline Likely (4) & Low Risk & Moderate & High Risk & Very High Risk (3.a., 4.e., 5.a.) & Very High Risk \\
\hline Possible (3) & Low Risk & Moderate (5.b.) & Moderate & High Risk (4.b.) & Very High Risk \\
\hline Unlikely (2) & Very Low Risk & Low Risk (1.c., 3.m.) & $\begin{array}{c}\text { Moderate (3.i., 3.j., } \\
\text { 4.c., 5.c., 5.d.) }\end{array}$ & Moderate (2.a., 2.b., 3.b.) & High Risk \\
\hline Very Unlikely (1) & Very Low Risk & Very Low Risk & $\begin{array}{c}\text { Low Risk (1.b., 2.c., } \\
\text { 3.e., 3.k., 3.1.) }\end{array}$ & Low Risk (1.a., 1.d., 3.c., 3.d., 4.a., 4.d.) & Moderate (3.g., 3.h.) \\
\hline
\end{tabular}




\section{DISCUSSION}

According to [28], to build accountability in the village's financial management, there are needs of mutual commitment and intensive supervision from its stakeholders. The use of funds as a village being a right is not seen as the absolute will of the village in carrying out its government. Because there are fund resources from the state budget (APBN), in managing its finances, the village must follow the rules set by the state. Therefore, principal-agent approach is used in analyzing potential problems in village financial management, where components such as adherence, clear authority, adequate resources, performance measures, and controls are essential in the successful management of the village, including the village finances.

Agency theory proposed by Lambert (2001) in [18] says that the principal provides capital and takes risk, while agents are expected to perform tasks, make decisions that favor the principal's interests, and take risks associated with the task. The agents may choose their own actions, steps, or decisions in doing the job. However, the principal is not fully able to pay attention to the options taken by the agent. Therefore, from the perspective of funds management in the villages related to APBN, APBD, and APBDesa acting as principal are the stakeholders of village financial management in this research, which can be interpreted as central government (the Ministry of Villages, for acceleration development backward regions, and transmigration of the Republic of Indonesia; the Ministry of Home Affairs of the Republic of Indonesia; and the Ministry of Finance of the Republic of Indonesia) central Lombok District Government (DPMD), and the Barabali village community. While the agent in village financial management is the Barabali village government.

Additionally, Adams (1994) [19] argues that agency theory can also explain the positions, roles, and responsibilities of internal auditors within an organization. The internal auditor is the party in the organization that helps the principal to overcome the problems that exist in agency theory, and to conduct supervisory and coaching activities so that agent actions are in accordance with the principal's interests. In terms of village financial management, the inspectorate of central Lombok plays an important role in bridging the interests of principal and agent.

The concept of risk management of village's financial activities at Barabali village is already embedded in the culture of the Barabali village government but has not been written in administrative form. It is very important to undertake risk management. According to [5] all activities must involve risk. Therefore, managing risk is something that can help us in overcoming or facing risks. Recognizing and understanding how to handle risks are the key benefit of risk management on village financial management at Barabali village. With the existence of risk management in village financial management, DPMD could easily conduct directional monitoring to evaluate and guide villages. Additionally, not only is risk a concern of management (i.e., the Barabali village government) but it is also a matter of concern for internal auditors which include the inspectorate of central Lombok. According to [5], the internal auditor plays an important role in monitoring the risk management process, but has no primary responsibility to implement it. By implementing risk management in the village's financial activities, the task of the inspectorate of central Lombok supervision of the management of village's financial activities is expected to be facilitated.

\section{CONCLUSION}

The concept of risk management of village's financial activities prepared in this study comes from [13]. There are three steps in this study. The first step is identifying the risks. The second step is analyzing and determining the risk levels. The final step is composing the strategies against the risks. The instrument used to analyze the risks was taken from the combination of references in [14] and [15]. Based on these references, a risk management framework for village-level financial management was established. Based on the results of literature studies, observations, and interviews with several resource persons, thirty risks were identified.

We found that there were four risks at the planning stage, four risks at the disbursement stage, thirteen risks at implementation and administration stage, five risks at the reporting and accountability stages, and four risks at supervision stage. The results show three risks categorized as very high risk, two risks categorized as high risk, twelve risks categorized moderate, and thirteen risks classified as low risk. Overall, the level for all the risks involved in village financial activities in Barabali village is at moderate level.

\section{RESEARCH IMPLICATIONS}

The results of the identification and analysis of the village's financial risks are expected to provide an overview of what risks are encountered in village financial activities that affected management and where risks that need attention and priorities are addressed. The risk owner shall know what actions can be taken in mitigating the impact of those risks and those who are responsible for them. Additionally, this study provides an overview of just how the condition of financial management is in a village (i.e., Barabali village in central Lombok). Risk management of the village's financial activities is expected to be useful to provide recommendations and improvements for financial activities of villages in central Lombok. It also becomes a useful material for DPMD and the inspectorate in carrying out its duties and functions related to supervision and fostering of village financial management.

\section{VIII.LIMITATIONS OF THE STUDY}

This study was limited to the risk analysis in just one village, Barabali, considered good enough in terms of financial management by the regional government of central Lombok. Additionally, the risk assessment was undertaken at the activity level, rather than the organizational level, and has not explained the risk trends from one budget period to later ones.

\section{SUGgESTION FOR FURTHER RESEARCH}

- Increase the objective of the research by comparing financial management between villages. Researchers may compare villages that manage finances well and poorly, or villages which have distant geographic differences. Further research is expected to obtain more comprehensive conditions of a village's financial management in Indonesia; 
- Scholars might continue this research by looking at risk trends from one period to later ones or by setting risks at the organizational level.

\section{ACKNOWLEDGMENT}

This research was supported by Indonesia Endowment Fund for Education (LPDP). We thank Mr.Dwi Setiawan and Mrs. Rr. Trisacti Wahyunifor assistance and comments that greatly improved the manuscript. We would also like to show our gratitude to the Mr.Gede Harja Wasistha for sharing his pearls of wisdom with us during the course of this research, and we thank reviewers for their so-called insights. We are also immensely grateful to RPM FEB UI for their comments on an earlier version of the manuscript, although any errors are our own and should not tarnish the reputations of these esteemed persons.

\section{REFERENCES}

[1] Ministry of Finance. (2016b). Policy on the Allocation and Distribution of village fundsvillage funds in 2017. Workshop on the drafting of the Regional Head of Regulation on Procedures for the Distribution and Determination of Details of village fundsing FY 2017. Indonesia.

[2] Sohuturon, M. (2017). National Police of Indonesia Finds 214 Cases of village funds Abuse. Accessed January, $20 \quad 2018$. https://www.cnnindonesia.com/nasional/20171020112724-12249704/polri-temukan-214-kasus-penyalahgunaan-dana-desa.

[3] Aziz, M. A. A., Ab Rahman, H., Alam, M. M., \& Said, J. (2015). Enhancement of the Accountability of Public Sectors through Integrity Systems, Internal Control Systems and Leadership Practices: A Review Study. Procedia Economics and Finance, 28, 163-169.

[4] PricewaterhouseCoopers (PwC). (2015). Enterprise Risk Management in the Public Sector. 2015 Survey Result.

[5] The Institute of Internal Auditors (IIA). (2004). Applying COSO's Enterprise Risk Management - Integrated Framework. USA: The Institute of Internal Auditors.

[6] Sukrawan, A. A., \& Wing W. W. (2013). Implementation of Risk Management Framework for Implementation of Information System Outsourcing Project in BPK RI. Accessed January 20, 2018. ISSN 2301-4156.

[7] Government of the Republic of Indonesia. (2003). Law Number 17 Year 2003 regarding State Finance. Indonesia.

[8] Government of the Republic of Indonesia. (2005). Law Number 58 Year 2005 regarding Regional Financial Management. Indonesia.

[9] Ministry of Home Affairs. (2014). Regulation of the Minister of Home Affairs Number 113 Year 2014 on villages Financial Management. Indonesia.

[10] AIRMIC, ALARM, and IRM. (2010). A Structured Approach to Enterprise Risk Management and The Requirements of ISO 31000 . UK.
[11] Sawyer, L. B., \& Mortimer, A. D. (2003). Sawyer's Internal Auditing 6th Edition of The Modern Practice of Internal Auditing. USA: The Institute of Internal Auditors.

[12] Corruption Eradication Commission (KPK). 2015. Report on the Results of the Village Financial Management Review: Allocation of village fundsvillage funds and village fundsvillage funds. Jakarta.

[13] Project Management Institute. (2000). A Guide to the Project Management Body of Knowledge. USA.

[14] Ministry of Finance. (2016a). Decree of the Minister of Finance of the Republic of Indonesia Number 845/KMK.01/2016 on Guidelines for the Implementation of Risk Management in the Ministry of Finance. Indonesia.

[15] Indonesia National Government of Internal Audit (BPKP). (2012). Guidelines for Implementing Risk Assessment in Government Agencies. Indonesia: BPKP

[16] Fone, Martin and Peter C. Young. (2000). Public Sector Risk Management. Oxford: Butterworth-Heinemann.

[17] Internal Audit Community of Practice (IA CoP). (2014). Risk Assessment in Audit Planning: A Guide for Auditors on How to Access Risks When Planning Audit Work.

[18] Bouckova, M. (2015). Management Accounting and Agency Theory. Accessed January 25, 2018. doi: 10.1016/S2212-5671(15)00707-8.

[19] Ibtida, R. (2017). Program Design Work of Risk-Based Performance Audit on Cost Case Management for Supreme Court Supervisory Board. Thesis. University of Indonesia.

[20] Muda, P. (2017). Key Risk Indicators Design Analysis on Risk Management of Oil Palm Plantation Company (Case Study at PT $\mathrm{ABC})$. Thesis. University of Indonesia.

[21] Kartika, P. Y. (2016). Risk Analysis and Control Plan in the Selection Process of Goods/Services Provider by Procurement Unit of Ministry of Foreign Affairs. Thesis. University of Indonesia.

[22] Creswell, J. W. (2013). Research Design Qualitative, Quantitative, and Mixed Methods Approaches (4th ed.). California: SAGE Publication Inc.

[23] Sekaran, U., \& Roger, B. (2015). Research Methods for Business: A Skill-Building Approach 6th Edition. USA: Wiley.

[24] Audit board of Indonesia (BPK). (2017). Audit Reports on central Lombok Financial Statements for Fiscal Year 2016. Jakarta: audit board of Republic of Indonesia (BPK).

[25] Lombok Post. (2017). Rp.118.5 Billion village funds in central Lombok Has Been Delayed. Accessed January, 202018. http://www.lombokpost.net/2017/08/10/rp-1185-miliar-dana-desa-dilombok-tengah-tertunda/.

[26] Radar Lombok. (2017). Village Budget Corruption in central Lombok is Increasingly Severe. Accessed January, 202018. https://radarlombok.co.id/korupsi-anggaran-desa-di-loteng-makinparah.html. (diunduh pada tanggal 25 Desember 2017)

[27] DetikNTB. (2017). Barabali village Becomes National Accountability villages (DBIP) Champion. Accessed January, 202018. https://www.detikntb.com/breaking-news/desa-barabali-jadi-juaradbip-tingkat-nasional/

[28] Munir, B. (2017). Village Revolution, Backflow of Village Movement to Build Indonesia. Mataram: Regional Institute 104 